\section{Juridisk tungvekter om tvang}

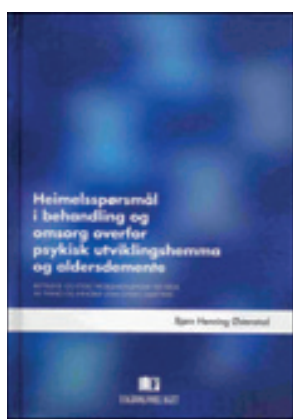

\author{
Bjørn Henning Østenstad \\ Heimelsspørsmål $\mathrm{i}$ behandling og omsorg \\ overfor psykisk utviklingshemma \\ og aldersdemente \\ Rettslege og etiske problemstillingar ved bruk \\ av tvang og inngrep utan gyldig samtykke. \\ 871 s, ill. Bergen: Fagbokforlaget, 2011. \\ Pris NOK 1198 \\ ISBN 978-82-450-1053-4
}

Dette er en juridisk doktoravhandling, skrevet av en jurist og, slik jeg ser det, først og fremst beregnet på jurister. Likevel vil den være av interesse og til nytte for flere grupper - for «lovsmeder» i departementene og for politikerne som vedtar lovene, for saksbehandlere hos tilsynsmyndighetene (Fylkesmann/Fylkeslege), for dem i kommunene som ofte blir involvert i beslutninger om å bruke tvang $i$ henhold til sosialtjenestelovens og pasientrettighetslovens kapitler som hjemler bruk av tvang (kapittel 4A i begge lover) og for dem som underviser på helse- og sosialfagutdanningene. Temaet er viktig for en større gruppe enn dette, men form og omfang gjør at målgruppen innskrenkes.

Boken er skrevet på nynorsk og språket er ikke utpreget akademisk - setningene er korte og konsise og logikken i kapitler og avsnitt er ryddig og klar. Slik sett er den lett å lese. Selv om det er en del juridiske faguttrykk som jeg (som ikke-jurist) har måttet slå opp, har ikke det vært noe stort problem. Det er en utstrakt bruk av fotnoter. De fyller flere funksjoner - som referanser, sitater, tilleggsinformasjon og forfatterens kommentarer til teksten. Dette reduserte lesbarheten for meg. Først forsøkte jeg å lese uten å bli avbrutt av fotnotene, men oppdaget snart at de av og til inneholdt poenger som var viktige for forståelsen av det som ble diskutert. Leseren bør ha ganske god kjennskap til norsk lovverk og til den europeiske menneskerettighetskonvensjon (eller sitte ved PC-en med lovdata.no oppslått).

Det er fem hoveddeler, som igjen er delt opp i underkapitler i flere nivåer $(1 ; 1.2 ; 1.3 .2$ osv. $)$ - opptil sju. Antall nivåer gjenspeiler hvor detaljert forfatteren diskuterer de forskjellige temaene.

Første del, Opptakt, er en kort (60 sider) introduksjon til temaområdet. I andre del, Det verdimessige bakteppet, går han systematisk inn i en rekke etiske og menneskerettslige diskusjoner. Jeg vil spesielt løfte frem hvordan forfatteren argumenterer for å forlate begrepet «samtykkekompetanse» til fordel for «selvbestemmelsesrett». Denne diskusjonen er grundig fundert og viktig for forståelsen av hva vi gjør når vi vurderer en persons «samtykkekompetanse». Den tredje delen, Når trengst heimel?, er mer omfattende (125 sider) og de juridisk-akademiske diskusjonene blir her mer fremtredende. Dette er på ingen måte uviktige diskusjoner, men det blir mye å lese for en lekmann, og noen av problemstillingene blir noe søkt i forhold til det som oppleves som realiteten i praksis. Det er likevel viktige poenger som kan anvendes i den kliniske hverdagen, særlig under diskusjonen om «inslagspunkt etter særlovgjevinga» (kap. 3.4 s. 242).

De to siste delene (Ulike heimlar for inngrep - hovedtrekk og utvalde dykk i djupna og Krav til heimelen) utgjør hoveddelen (s. 277-790). Her slår også juridisk argumentasjon og grundighet til. Det blir mye og omfattende lesning. Selv om store deler er detaljert og juridisk-akademisk, er det en rekke viktige forhold som diskuteres. Denne diskusjonen bør føres videre og få konsekvenser for hvordan kapitel 4A i både pasientrettighetsloven og sosialtjenesteloven tolkes og anvendes. Det gjelder særlig del 4, hvor forskjellige lovverk som hjemler tvang settes opp mot hverandre og ses i forhold til hverandre og det diskuteres hvordan de kan forstås i sammenheng. Ett eksempel er hvorvidt det bør åpnes for behandling med antipsykotika (med tvang) der det ikke er stilt en psykiatrisk diagnose (s. 516).
Dette er et imponerende og omfattende arbeid som på en forståelig måte har brakt meg lenger inn i juridisk tenkning på et område jeg har vært opptatt av lenge. Det har gitt meg nye innfallsvinkler og tanker som har resultert $\mathrm{i}$ at jeg nok har revurdert mitt syn på en del ting, men det har vært krevende lesning. Dette er ikke noen lærebok eller noe oppslagsverk (i hvert fall ikke før man har lest ferdig). Det er stoff til refleksjon og ettertanke.

Heimelsspørsmål $i$ behandling og omsorg overfor psykisk utviklingshemma og aldersdemente må leses fra starten og utover. Den starter med det enkle og lett tilgjengelige stoffet, så blir det mer krevende etter hvert. Del 1 og del 2 bør kunne leses av alle, del 3 er såpass kort og med så mange viktige diskusjoner at de fleste som involveres i situasjoner der det kan være aktuelt å bruke tvang, vil oppleve dette som nyttig. Del 4 er tyngre, men likevel aktuell, kanskje mest for gruppen som er nevnt innledningsvis. Femte del er den mest jusspesifikke og mest krevende.

Dette er meget nyttig lesning, men jeg kunne ønske meg en kortere versjon for ikke-jurister.

\section{Øyvind Kirkevold}

Nasjonalt kompetansesenter for aldring og helse Tønsberg

\section{En viktig film}

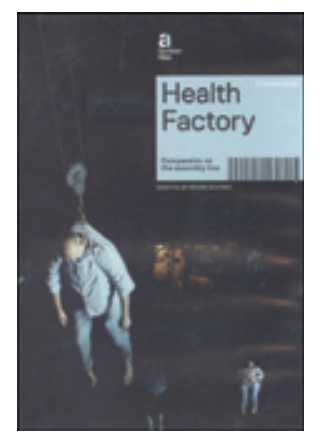

Håvard Bustnes, reg. Health factory (Helsefabrikken) Compassion on the assembly line. DVD: 58 min. Trondheim: Faction film, 2010. Pris EUR 27

I Modern times fra 1936 spiller Charlie Chaplin (1889-1977) «landstrykeren». Dette er en film med økonomiske nedgangstider og industrialisering som bakgrunn. Fabrikkens samlebånd med krav til disiplin og flid er en stor prøvelse for en av filmhistoriens aller største rollefigurer. Med helseforetaksreformen og new public management kom et nytt tenkesett inn i norske sykehus - markedsmekanismene og dermed gjorde økonomene og juristene sitt inntog, det ble byråkratisering og en tellekultur. Sykehusspråket ble endret - lønnsomhet, overskudd (!), produksjon, benchmarking, prosjekter, outsourcing o.l. erstattet behandling av syke, omsorg og honnørordene helbrede, lindre og trøste.

Dette tar Håvard Bustnes tak i med sin kritiske dokumentarfilm om dagens norske helsevesen. Det er ingen tradisjonell, nøytral dokumentar. Den stimulerer til refleksjon og ettertanke. Noen begeistres, andre irriteres. Det er en bevisst provokasjon, med tidvis sterke og til dels makabre virkemidler og retoriske grep. Filmskaperen har et budskap, og det finnes helter og skurker. Heltene fremstilles i harmoniske omgivelser, mens skurkene - Margaret Thatcher (f. 1925) og Bjarne Håkon Hanssen (f. 1962) - utsettes for helt andre grep. Vi følger den tidligere helseministeren på besøk til Toyotas bilfabrikk, hvor nettopp samlebåndet blir inspirasjon for et effektivt sykehus! NRK klippet filmen før visning sist vinter. Nærbilder av stoppeklokkn i hånden på konsulenter fra firmaet Ernst \& Young ble fjernet. Virkemidlene ble for sterke.

Filmen setter bl.a. søkelys på DRG-poeng i fødselsomsorgen. Omsorg gir liten uttelling, komplikasjoner bringer penger i kassen. Diagnoser omgjøres til økonomi, behandling blir produksjon, helseforetakene (sykehusene) skal gå med overskudd - hva med de ansatte? 